\title{
REDISTRIBUSI KEKUASAAN NEGARA DAN HUBUNGAN ANTAR LEMBAGA NEGARA DI INDONESIA
}

\author{
Oleh: \\ Rahmat Robuwan, S.H., M.H.*
}

\begin{abstract}
The relationship between state agencies basically can not be separated from the system used by the state government itself. Indonesia as a country that adopts a presidential government certainly has a pattern of distribution of power, although theoretically the presidential government system power state agency separate (separation of power), but the relationship between institutions is not a relative. The mechanism of checks and balances of power destribusi state institutions. Before the amendment, the agency is the State Supreme People's Representative Council (DPR), the President, the Supreme Audit Agency CPC, the Supreme Advisory Council (DPA) and the Supreme Court with the vertical power distribution. Following the amendment to the state institutions teridir of the President, the People's Consultative Assembly (MPR), House of Representatives (DPR), the Regional Representatives Council (DPD), the Supreme Audit Agency (BPK), the Supreme Court (MA), and the Constitutional Court (MK) with distribution horizontal power - functional. The distribution of power still has a problem among others, the discontinuity in the distribution of state agencies ranging from the overlapping powers of the president in participating deliberating the bill with the House, the confusion related to the division between the authority of the Supreme Court and the Constitutional Court in the perspective of the state administration, the inconsistency of the parliamentary system that it wants to apply and the lack of authority DPD in parliament.
\end{abstract}

Keywords; Presidential System of government, Check and Balance, Trias Politica

\section{A. PENDAHULUAN}

Salah satu ciri negara hukum adalah adanya ciri pembatasan kekuasaan dalam penyelenggaraan kekuasaan negara. ${ }^{1}$ Pembatasan itu dilakukan dengan hukum yang kemudian menjadi ide dasar paham konstitualisme modern. Oleh karena itu, konsep negara hukum yang juga

\footnotetext{
*Dosen Tetap Fakultas Hukum Universitas Bangka Belitung.

${ }^{1}$ Dalam bahasa Inggris disebut the rule of law atau dalam bahasa Belanda disebut rechstaat,
}

disebut sebagai negara konstitusional, yaitu negara yang dibatasi oleh konstitusi. Dalam konteks yang sama gagasan negara demokrasi atau kedaulatan rakyat disebut pula dengan istilah constitutional democracy yang dihubungkan dengan pengertian negara demokrasi yang berdasarkan atas hukum.

Upaya pembatasan juga dilakukan dengan mengadakan pola-pola pembatasan kekuasaan di dalam 
pengelolaan internal kekuasaa negara itu sendiri, yaitu dengan membedakan dan pemisahan kekuasaan negara ke dalam beberapa fungsi yang berbedabeda. Dalam hubungan ini, yang dapat dianggap paling berpengaruh pemikirannya dalam mengadakan pembedaan fungsi-fungsi kekuasaan itu adalah Mountesquieu dengan teori trias politica-nya, yaitu cabang kekuasaan legislatif, eksekutif atau administratif, dan yudikatif. ${ }^{2}$

Menurut Montesquieu dalam bukunya “L'esprit des Lois" (1978) yang mengikuti jalan pikiran John Locke, membagi kekuasaan negara dalam tiga cabang yaitu kekuasaan legislatif sebagai pembuat undangundang, kekuasaan eksekutif sebagai yang melaksanakan, dan kekuasaan untuk menghakimi atau yudikatif. Dari klasifikasi Montesquieu inilah dikenal pembagian kekuasaan negara modern dalam tiga fungsi yaitu legislatif (the legislative function), eksekutif (the executive or administrative function) dan yudisial (the judicial function).

Sebelumnya John Locke juga membagi kekuasaan dalam tiga fungsi, tetapi berbeda isinya. Menurut John

2 Jimly Asshiddiqie, 2006, Pengantar Hukum Tata Negara Jilid II, Sekretariat jendral dan Kepaniteraan Mahkamah Konstitusi, Jakarta. hlm. 11-12.
Locke fungsi-fungsi kekuasaan itu meliputi fungsi legislatif, fungsi eksekutif, dan fungsi federatif. Dapat dilihat pendapat keduanya berbeda. Montequieu lebih melihat pembagian atau pemisahan kekuasaan itu dari segi hak asasi manusia setiap warga negara, sedangkan John Locke lebih melihatnya dari hubungan ke dalam dan keluar dengan negara-negara lain. Bagi John Locke penjelmaan fungsi defencie baru timbul apabila fungsi diplomacie terbukti gagal. Oleh sebab itu, yang dianggap penting adalah fungi federatif. Sedangkan fungsi yudisial bagi Locke cukup dimasukkan kedalam kategori fungsi legislatif, yaitu terkait dengan fungsi pelaksanaan hukum. Tetapi bagi Montesquieu, fungsi pertahanan (defence) dan hubungan luar negerilah (diplomasi) yang termasuk kedalam eksekutif, sehingga tidak perlu disebut tersendiri. Justru dianggap penting oleh Montesquieu adalah fungsi yudisial atau fungsi kekuasaan kehakiman. $^{3}$

Di samping itu, dalam studi ilmu administrasi publik atau public administration dikenal pula adanya teori yang membagi kekuasaan ke dalam dua fungsi saja. Kedua fungsi

${ }^{3}$ Ibid., hlm. 13. 
itu adalah fungsi pembuatan kebijakan (policy making function) dan fungsi pelaksanaan kebijakan (policy executing function). Semua usaha membagi dan membedakan serta memisah-misahkan fungsi-fungsi kekuasaan itu ke dalam beberapa cabang, pada pokoknya adalah dalam rangka untuk membatasi kekuasaan itu sendiri sehingga tidak terjadi sumber kesewenang-wenangan.

Seperti diuraikan di atas persoalan pembatasan kekuasaan (limitation of power) berkaitan erat dengan teori pemisahan kekuasaan (separation of power) dan teori pembagian kekuasaan (division of power atau distribution of power). Pada umumnya, doktrin pemisahan kekuasaan atau pembagian kekuasaan dianggap berasal dari Montesquieu dengan trias politica-nya. Namun dalam perkembangannya banyak versi yang biasa dipakai oleh para ahli berkaitan dengan peristilahan pemisahan dan pembagian kekuasaan. ${ }^{4}$

Undang-Undang Dasar Negara Republik Indonesia Tahun 1945 (UUD NRI 1945) merupakan satu kesatuan rangkaian perumusan hukum dasar Indonesia. Isinya mencakup dasar-dasar normatif yang berfungsi sebagai sarana pengendali (tool of social and political control) terhadap penyimpangan dan penyelewengan dalam dinamika perkembangan zaman dan sekaligus sarana pembaruan masyarakat (tool of social and political reform) serta sarana perekayasaan (tool of social and political engineering) ke arah cita-cita kolektif bangsa. Kesuluruhan kesepakatan yang menjadi materi konstitusi pada intinya menyangkut prinsip pengaturan dan pembatasan kekuasaan.

Konstitusionalisme mengatur dua hubungan yang saling berkaitan satu sama lain, yaitu; pertama, hubungan antara pemerintah dengan warga negara; dan kedua, hubungan antara lembaga pemeritahan yang satu dengan lembaga pemerintahan yang lain. Karena itu, biasanya, isi konstitusi dimaksudkan untuk mengenai tiga hal penting, yaitu; (a) menentukan pembatasan kekuasaan organ-organ negara; (b) mengatur hubungan antara lembaga-lembaga negara yang satu dengan yang lain; (c) mengatur hubungan kekuasaan 
lembaga-lembaga negara dengan warga negara. ${ }^{5}$

Dalam sistem ketatanegaraan Indonesia, UUD NRI 1945 dengan jelas membedakan cabang-cabang kekuasaan negara dalam bidang legislatif, eksekutif, dan yudikatif yang tercermin dalam fungsi-fungsi MPR, DPR dan DPD, Presiden dan Wakil Presiden, serta Mahkamah Agung, Badan Pemeriksa Keuangan, dan Mahkamah Konstitusi sebagai lembaga-lembaga negara yang utama. Lembaga-lembaga negara dimaksud itulah yang secara instrumental menjadi pelembagaan fungsi-fungsi kekuasaan negara yang utama, sehingga lembaga-lembaga negara itu pula yang dapat disebut sebagai lembaga negara utama yang hubungannya dengan yang lain diikat oleh prinsip checks and balance. Di samping lembaga-lembaga yang bersifat utama yang biasa disebut sebagai lembaga tinggi negara seperti yang dimaksud di atas ada juga lembaga-lembaga negara yang bersifat konstitusional lainnya seperti Komisi

\footnotetext{
5 Jimy Asshiddiqie, 2009, Menuju Negara Hukum yang Demokratis, PT. Buana Ilmu Populer, Jakarta, hlm. 455.
}

Yudisial, Kepolisian, TNI, Bank Indonesia, KPU, dan sebagainya. ${ }^{6}$

Berkaitan dengan keadaan tersebut dalam suatu sistem ketatanegaraan setidaknya terdapat tiga kelompok lembaga negara; (1) lembaga negara yang ditentukan dalam UUD; (2) lembaga negara yang ditentukan oleh UU; (3) lembaga negara yang ditentukan oleh Keputusan Presiden. Mencermati hal tersebut Sri Soemantri menganalisis dan berpendapat bahwa untuk sistem ketatanegaraan Indonesia yang berkenaan dengan lembaga negara yang ada dalam UUD, hal itu berkaitan dengan sistem ketatanegaraan dalam arti sempit. Sedangkan jika dimaksud juga dengan lembaga negara di luar UUD, hal ini berkenaan dengan sistem ketatanegaraan dalam arti luas. $^{7}$

Pada dasarnya dalam suatu negara hukum yang terpenting bukan ada atau tidaknya konsep trias politica itu, akan tetapi persoalannya adalah dapat atau tidak kah alat-alat kekuasaaan negara itu dihindarkan dari praktikpraktik kekuasaan birokrasi dan tirani.

\footnotetext{
${ }^{6}$ Lihat Putusan Nomor 005/PUU-IV/ tentang Judicial Review terhadap Undang-Undang no. 22Tahun 2004 tentang Komisi Yudisial.

${ }^{7}$ Sri Soemantri, 2008, Lembaga Negara dan State Auxiliary Bodies dalam Sistem Ketatanegaraan Menurut UUD 1945, Departemen Hukum Fakultas Hukum Unair, hlm. 196.
} 
Dan hal ini tidaklah tergantung kepada pemisahan ataupun pembagian kekuasaan itu sendiri, akan tetapi akan adanya sendi negara demokrasi yang berkedaulatan rakyat. $^{8}$ Merupakan sifat khusus pada suatu negara adalah dengan memiliki kekuasaan untuk membuat dan melaksanakan undangundang dengan segala cara maupun paksaan yang diperlakukan. Kekuasaan seperti ini disebut kedaulatan (sovereignty). Kedaulatan dapat dibedakan dalam arti internal dan eksrternal. Di mana secara internal, istilah ini bermakna supremasi perorangan atau sekumpulan individu dalam suatu wilayah yurisdiksinya. Secara eksternal, berarti independensi mutlak satu negara sebagai suatu keseluruhan dalam hubungannya dengan negaranegara lainnya. ${ }^{9}$

Berdasarkan uraian singkat di atas kemudian menarik kiranya ketika harus membicarakan terkait redistribusi kekuasaan di Indonesia sebelum dan sesudah amandemen terkait apa-apa yang menjadi kewenangan antar lembaga kekuasaan, batasan-batasan kewenangannya serta

8 Ismail Suny, 1986, Pergeseran Kekuasaan Eksekutif, cetakan ke-5, Aksara Baru, jakarta, hlm. 16.

${ }^{9}$ C.F. Strong, "Modern Political Constitusional", terjemahan cetakan ke-10, Nusa Media, Bandung, hlm. 8. hubungan antar lembaga negara dalam kaitannya dengan konsep check and balances. Rumusan masalah yang disampaikan; (1) bagaimanakah redistribusi kekuasaan lembaga negara sebelum dan sesudah amandemen UUD NRI 1945?; (2) Bagaimanakah hubungan antara lembaga negara (checks and balance)?; (3) Apa saja kontroversi dalam redistribusi kekuasaan di negara Indonesia berdasarkan UUD NRI 1945?

\section{B. PEMBAHASAN}

\section{Distribusi Kekusasaan Lembaga} Negara Sebelum dan Sesudah Amandemen UUD 1945

Undang-undang dibuat harus sesuai dengan keperluan dan harus peka zaman, artinya aturan yang dibuat oleh DPR sebelum di sahkan menjadi undang- undang sebelumnya harus disosialisasikan dahulu dengan rakyat, apakah tidak melanggar norma- norma adat atau melanggar hak - hak asasi manusia. Salah satu bukti bahwa undangundang yang sudah tidak relevan lagi dengan kondisi zamanya adalah UUD NRI 1945. Dengan mengalami empat kali perubahan yang masing - masing tujuannya tidak lain hanya untuk bisa sesuai dengan kehendak rakyat dan 
bangsa kita, dalam arti bisa mewakili aspirasi rakyat yang disesuaikan zamanya, di mana dalam amandemen yang ke 4 rakyat memegang kekuasaan yang paling tinggi, sangat berbeda dengan sebelum amandemen yang MPR merupakan wakil rakyat untuk mewujudkan aspirasinya yang salah satu tugasnya adalah dalam memilih Presiden dan Wakil Presiden, karena dianggap sebagai bentuk pemerintahan yang korup, syarat dengan aroma $\mathrm{KKN}$ yang membentuk kekuasaan tak terbatas terhadap Presidennya. Kita tahu bahwa dalam masa Orde Baru Presiden kita tidak pernah mengalami pergantian selama 32 tahun meski telah mengalami Pemilihan Umum sebanyak tidak kurang dari 6 kali Pemilu. Oleh sebab itu para mahasiswa kita dan para aktivis lainya mengadakan Reformasi yang berimbas juga pada reformasi didalam isi UUD NRI 1945.

Adapun perbedaan kelembagaan dan tugas kenegaraaan sebelum dan sesudah amandemen UUD NRI 1945, yaitu;
Sebelum Amandemen UUD NRI 1945

Pada saat sebelum amandemen, lembaga tertinggi negara adalah MPR seperti yang tersebut dalam UUD NRI 1945 pasal 1 ayat (2) menyebutkan bahwa kedaulatan adalah di tangan rakyat dan dilakukan sepenuhnya oleh Majelis Pemusyarawatan Rakyat. Adapun lembaga tinggi negara pada saat itu adalah Dewan Perwakilan Rakyat (DPR), Presiden, Badan Pemeriksa Keuangan (BPK), Dewan Pertimbangan Agung (DPA) dan Mahkamah Agung. Berikut bagan lembaga negara sebelum amandemen UUD NRI 1945;

1. MPR

Sebagai lembaga tertinggi negara diberi kekuasaan tak terbatas (super power) karena "kekuasaan ada di tangan rakyat dan dilakukan sepenuhnya oleh MPR” dan MPR adalah "penjelmaan dari seluruh rakyat Indonesia" yang berwenang menetapkan UUD, GBHN, mengangkat presiden dan wakil presiden.

Susunan keanggotaannya terdiri dari anggota DPR dan utusan daerah serta utusan golongan yang diangkat. 
Dalam

praktik

ketatanegaraan, MPR pernah

menetapkan antara lain:

a. Presiden, sebagai presiden seumur hidup.

b. Presiden yang dipilih secara terus menerus sampai 7 (tujuh) kali berturut turut.

c. Memberhentikan sebagai pejabat presiden.

d. Meminta presiden untuk mundur dari jabatannya.

e. Tidak memperpanjang masa jabatan sebagai presiden.

f. Lembaga Negara yang paling mungkin menandingi MPR adalah Presiden, yaitu dengan memanfaatkan kekuatan partai politik yang paling banyak menduduki kursi di MPR.

\section{Presiden/ Wapres}

Karakteristrik kekuasaan presiden memiliki kewenangan yang besar yaitu:

a. Presiden memegang posisi sentral dan dominan sebagai mandataris MPR, meskipun kedudukannya tidak "neben" akan tetapi "untergeordnet".

b. Presiden menjalankan kekuasaan pemerintahan negara tertinggi (consentration of power and responsiblity upon the president).

c. Presiden selain memegang kekuasaan eksekutif (executive power), juga memegang kekuasaan legislative (legislative power) dan kekuasaan yudikatif (judicative power).

d. Presiden mempunyai hak prerogatif yang sangat besar.

e. Tidak ada aturan mengenai batasan periode seseorang dapat menjabat sebagai presiden serta mekanisme pemberhentian presiden dalam masa jabatannya.

3. DPR

Beberapa Kewenangan DPR yaitu:

a. Memberikan persetujuan atas RUU yang diusulkan presiden.

b. Memberikan persetujuan atas PERPU.

c. Memberikan persetujuan atas Anggaran.

d. Meminta MPR untuk mengadakan sidang istimewa guna meminta pertanggungjawaban presiden. 
4. DPA dan BPK

Di samping itu, UUD 1945 tidak banyak mengintrodusir lembaga-lembaga negara lain seperti DPA dan BPK dengan memberikan kewenangan yang sangat minim.

5. Mahkamah Agung

Merupakan lembaga tinggi negara dari peradilan Tata Usaha Negara, PN, PA, dan PM.

\section{Sesudah Amandemen UUD 1945}

Sebagai kelembagaan negara, MPR RI tidak lagi diberikan sebutan sebagai lembaga tertinggi negara dan hanya sebagai lembaga negara, seperti juga DPR, Presiden, BPK dan MA. Dalam pasal 1 ayat (2) yang telah mengalami perubahan perihal kedaulatan disebutkan bahwa kedaulatan berada di tangan rakyat dan dilaksanakan menurut undangundang dasar sehingga tampaklah bahwa MPR RI tidak lagi menjadi pelaku/ pelaksana kedaulatan rakyat. Juga susunan MPR RI telah berubah keanggotaannya, yaitu terdiri atas anggota DPR dan Dewan Perakilan Daerah (DPD), yang kesemuannya direkrut melalui pemilu.

Perlu dijelaskan pula bahwa
susunan ketatanegaraan dalam
kelembagaan negara juga
mengalami perubahan, dengan
pemisahan kekuasaan, antara lain
adanya lembaga negara yang
dihapus maupun lahir baru, yaitu sebagai badan legislatif terdiri dari anggota MPR, DPR, DPD, badan eksekutif Presiden dan Wakil Presiden, sedang badan yudikatif terdiri atas kekuasaan kehakiman yaitu Mahkamah Konstitusi (MK) sebagai lembaga baru, Mahkamah Agung (MA), dan Komisi Yudisial (KY) juga lembaga baru. lembaga negara lama yang dihapus adalah dewan Pertimbangan Agung (DPA), dan Badan Pemeriksa Keuangan tetap ada hanya diatur tersendiri diluar kesemuanya/ dan sejajar.

Undang-Undang Dasar merupakan hukum tertinggi di mana kedaulatan berada di tangan rakyat dan dijalankan sepenuhnya menurut UUD. UUD NRI 1945 memberikan pembagian kekuasaan (separation of power) kepada 6 lembaga negara dengan kedudukan yang sama dan sejajar, yaitu Presiden, Majelis Permusyawaratan 
Rakyat (MPR), Dewan Perwakilan

Rakyat (DPR), Dewan Perwakilan

Daerah (DPD), Badan Pemeriksa

Keuangan (BPK), Mahkamah Agung (MA), dan Mahkamah Konstitusi (MK). Perubahan (amandemen) UUD NRI 1945 di antaranya mencakup;

1. Mempertegas prinsip negara berdasarkan atas hukum [Pasal 1 ayat (3)] dengan menempatkan kekuasaan kehakiman sebagai kekuasaan yang merdeka, penghormatan kepada hak asasi manusia serta kekuasaan yang dijalankan atas prinsip due process of law.

2. Mengatur mekanisme pengangkatan dan pemberhentian para pejabat negara, seperti hakim.

3. Sistem konstitusional berdasarkan perimbangan kekuasaan (check and balances) yaitu setiap kekuasaan dibatasi oleh undang-undang berdasarkan fungsi masingmasing.

4. Setiap lembaga negara sejajar kedudukannya di bawah UUD NRI 1945.

5. Menata kembali lembagalembaga negara yang ada serta membentuk beberapa lembaga negara baru agar sesuai dengan sistem konstitusional dan prinsip negara berdasarkan hukum.

6. Penyempurnaan pada sisi kedudukan dan kewenangan maing-masing lembaga negara disesuaikan dengan perkembangan negara demokrasi modern.

Tugas lembaga tinggi negara sesudah amandemen ke-4 UUD NRI 1945 dapat dirumuskan pada penjelasan di bawah ini;

1. MPR

Karakteristik posisi lembaga MPR setelah amandemen dapat dirumuskan sebagai berikut:

a. Lembaga tinggi negara sejajar kedudukannya dengan lembaga tinggi negara lainnya seperti Presiden, DPR, DPD, MA, MK, dan BPK.

b. Menghilangkan supremasi kewenangannya.

c. Menghilangkan kewenangannya menetapkan GBHN.

d. Menghilangkan kewenangannya mengangkat Presiden (karena presiden dipilih secara langsung melalui pemilu). 
e. Tetap berwenang menetapkan dan mengubah UUD.

f. Susunan keanggotaanya berubah, yaitu terdiri dari anggota Dewan Perwakilan Rakyat dan anggota Dewan Perwakilan Daerah yang dipilih secara langsung melalui pemilu.

Tugas dan kewenagan MPR RI sesudah perubahan, menurut pasal 3 UUD NRI 1945 (perubahan ketiga);

a. Majelis Permusyawaran Rakyat berwenang mengubah dan menetapkan UUD.

b. Majelis Permusyawaran Rakyat melantik Presiden dan/ atau Wakil Presiden.

c. Majelis Permusyawaran Rakyat hanya dapat memberhentikan presiden dan/atau Wakil Presiden dalam masa jabatannya menurut undang-undang dasar (impeachment).

2. DPR

Karakteristik posisi DPR pasca amandemen dapat dilihat pada rumusan di bawah ini:

a. Posisi dan kewenangannya diperkuat. b. Mempunyai kekuasan membentuk UU (sebelumnya ada di tangan presiden, sedangkan DPR hanya memberikan persetujuan saja) sementara pemerintah berhak mengajukan RUU.

c. Proses dan mekanisme membentuk UU antara DPR dan Pemerintah.

d. Mempertegas fungsi DPR, yaitu fungsi legislasi, fungsi anggaran, dan fungsi pengawasan sebagai mekanisme kontrol antar lembaga negara.

3. DPD

Lembaga DPD merupakan lembaga baru yang dibentuk dan diproyeksikan untuk;

a. Lembaga negara baru sebagai langkah akomodasi bagi keterwakilan kepentingan daerah dalam badan perwakilan tingkat nasional setelah ditiadakannya utusan daerah dan utusan golongan yang diangkat sebagai anggota MPR.

b. Keberadaanya dimaksudkan untuk memperkuat Negara Kesatuan Republik Indonesia. 
c. Dipilih secara langsung oleh masyarakat di daerah melalui pemilu.

d. Mempunyai kewenangan mengajukan dan ikut membahas RUU yang berkaitan dengan otonomi daerah, hubungan pusat dan daerah, RUU lain yang berkait dengan kepentingan daerah.

4. BPK

Karakteristik lembaga BPK pasca amandemen yaitu;

a. Anggota BPK dipilih DPR dengan memperhatikan pertimbangan DPD.

b. Berwenang mengawasi dan memeriksa pengelolaan keuangan negara (APBN) dan daerah (APBD) serta menyampaikan hasil pemeriksaan kepada DPR dan DPD dan ditindaklanjuti oleh aparat penegak hukum.

c. Berkedudukan di ibukota negara dan memiliki perwakilan di setiap provinsi.

d. Mengintegrasi peran BPKP sebagai instansi pengawas internal departemen yang bersangkutan ke dalam BPK.
5. Presiden

Kekuasaan presiden pasca amandemen ini mendapat fokus yang besar dalam perubahannya yaitu:

a. Membatasi beberapa kekuasaan presiden dengan memperbaiki tata cara pemilihan dan pemberhentian presiden dalam masa jabatannya serta memperkuat sistem pemerintahan presidensial.

b. Kekuasaan legislatif sepenuhnya diserahkan kepada DPR.

c. Membatasi masa jabatan presiden maksimum menjadi dua periode saja.

d. Kewenangan pengangkatan duta dan menerima duta harus memperhatikan pertimbangan DPR.

e. Kewenangan pemberian grasi, amnesti dan abolisi harus memperhatikan pertimbangan DPR.

f. Memperbaiki syarat dan mekanisme pengangkatan calon presiden dan wakil presiden menjadi dipilih secara langsung oleh rakyat melui pemilu, juga mengenai pemberhentian jabatan 
presiden dalam masa jabatannya.
Kepolisian,

Advokat/

Pengacara dan lain-lain.

7. Mahkamah Konstitusi

Dibentuknya lembaga Mahkamah Konstitusi ini dilakukan dengan tujuan dan posisi yaitu;

a. Keberadaanya dimaksudkan sebagai penjaga kemurnian konstitusi (the guardian of the constitution).

b. Mempunyai kewenangan: menguji UU terhadap UUD, memutus sengketa kewenangan antar lembaga negara, memutus pembubaran partai politik, memutus sengketa hasil pemilu dan memberikan putusan atas pendapat DPR mengenai dugaan pelanggaran oleh presiden dan atau wakil presiden menurut UUD.

c. Hakim Konstitusi terdiri dari 9 orang yang diajukan masing-masing oleh Mahkamah Agung, DPR dan pemerintah dan ditetapkan oleh Presiden, sehingga mencerminkan perwakilan dari 3 cabang kekuasaan negara yaitu yudikatif, legislatif, dan eksekutif. 
8. Komisi Yudisial

Komisi Yudisial bertugas mencalonkan Hakim Agung dan melakukan pengawasan moralitas dan kode etik para Hakim.

\section{Hubungan Lembaga Negara} (Check and Balance)

Ketika gerakan reformasi
berhasil menjebol tembok
sakralisasi UUD NRI 1945, banyak
hal yang dikemukakan oleh
masyarakat, terutama kalangan
akademisi, berkaitan dengan
gagasan untuk memperbaiki UUD
agar ia mampu membangun sistem
politik dan ketatanegaraan yang
demokratis. Gagasan ini menjadi
niscaya karena selama berlakunya
UUD NRI 1945 dalam tiga periode
sistem politik ternyata di Indonesia
tak pernah lahir sistem politik yang
demokratis sehingga selalu timbul
korupsi dalam berbagai bidang
kehidupan.
Salah satu gagasan perubahan
yang ketika itu ditawarkan adalah
usulan tentang sistem dan
mekanisme cheks and balances itu
tidak ada. Dalam pembuatan
undang-undang misalnya,
seluruhnya didominasi oleh

eksekutif, baik proses inisiatifnya maupun pengesahannya. Selama era Orde Baru, tidak pernah ada RUU datang dari inisiatif Dewan Perwakilan Rakyat (DPR). Bahkan RUU yang semula berasal dari presiden pun pernah ditolak untuk disahkan oleh DPR melalui pembahasan bersama pemerintah selama tak kurang dari delapan bulan. ${ }^{10}$ Dominasi eksekutif dalam membuat, melaksanakan, dan menafsirkan undang-undang menjadi begitu kuat di dalam sistem politik yang executive heavy karena tidak ada peluang pengujian atas undang-undang oleh lembaga yudisial dalam apa yang dikenal sebagai judicial review atau (constitusional review) seperti sekarang. Review atas undangundang hanya dapat dilakukan oleh lembaga legislatiF melalui legislative review dan political review padahal lembaga tersebut didominasi oleh presiden.

Itulah sebabnya, ketika reformasi membuka pintu bagi dilakukannya amandemen atas UUD NRI 1945, maka yang cukup menonjol disuarakan adalah

\footnotetext{
${ }^{10}$ Moh. Mahfud MD, 2013 , Perdebatan Hukum Tata Negara Pascaamandemen Konstitusi, Raja Grafindo Persada, Jakarta, hlm.67
} 
memasukan checks and balences antara lembaga legislatif, lembaga eksekutif, dan lembaga yudikatif. Hal Ini kemudian diterima, dan secara fundamental mengubah sistem ketatanegaraan kita khususnya terkait dengan kedudukan lembaga negara yang diatur dalam UUD NRI 1945 serta hubungan atara lembaga negara tersebut. $^{11}$

Hubungan antar lembaga negara yang telah diatur dalam UUD NRI 1945 antara lain;

1. Hubungan DPR dengan DPD Adapun pola hubungan antara lembaga DPR dan DPD yaitu;

a. Ada hubungan antara DPR dan DPD. Hal itu tertera dalam UUD NRI 1945 pasal 22D ayat 1 yaitu dalam rangka otonomi daerah antara pemerintah pusat dan daerah itu digabungkan untuk mengelola sumber daya alam dan sumber daya ekonomi lainnya serta yang berkaitan dengan perimbangan keuangan pusat dan daerah, Yang kesemuanya itu untuk perkembangan daerah.

${ }^{11}$ Ibid., hlm.68

b. Setelah DPD mengajukan RUU ke DPR kemudian DPD dapat ikut membahas RUU yang berkaitan yang berkaitan dengan otonomi daerah.

c. Sesuai dengan kewenangannya DPD menyampaikan hasil pengawasan pelaksanaan undang-undang tertentu kepada DPR.

d. DPD memberikan pertimbangan terhadap pemilihan anggota BPK yang dipilih oleh Dewan Perwakilan Rakyat.

e. DPD memberikan pertimbangan kepada DPR atas RUU APBN dan RUU yang berkaitan dengan pajak, pendidikan, dan agama.

f. DPD dapat mengajukan usul dan ikut dalam pembahasan dan memberikan pertimbangan yang berkaitan dengan bidang legislasi tertentu.

g. DPR menerima dan membahas usulan RUU yang diajukan DPD yang berkaitan dengan bidang tertentu dan mengikutsertakannya dalam pembahasan. 
2. Hubungan DPR dengan Presiden

Adapun pola hubungan antara lembaga DPR dan Presiden yaitu;

a. Hubungan antara DPR dan Presiden adalah DPR dapat mengajukan usulan Rancangan Undang - Undang dalam persidangan Dewan Perwakilan Rakyat. Kemudian hubungannya dengan Presidean adalah Presiden yang mengesahkan atau menyetujui Rancangan Undang - Undang tersebut.

b. Dalam hal membahas Rancang Undang - Undang, DPR dan Presiden adalah mitra yang sejajar karena kedua - duanya bersama sama membahas RUU tersebut yang kemudian untuk mendapatkan persetujuan bersama.

c. Dalam hal ikhwal kepentingan yang memaksa, Presiden berhak menetapkan Peraturan Pemerintah sebagai penggnti Undang - Undang. Sedangkan Peraturan

Pemerintah itu disetujui oleh Dewan Perwakilan Rakyat. d. Presiden meresmikan anggota BPK yang telah dipilih dan ditetapkan oleh Dewan Perwakilan Rakyat dengan memperhatikan pertimbangan Dewan Perwakilan Daerah.

e. DPR memberikan persetujuan kepada Presiden untuk mengangkat dan memberhentikan anggota Komisi Yudisial.

f. DPR memberikan persetujuan kepada Presiden dalam menetapkan Hakim Agung dari calon yang diusulkan oleh Komisi Yudisial.

g. Presiden secara bersama dengan DPR dan M K mengajukan calon.

h. Hakim Konstitusi masingmasing 3 orang serta menetapkan hakim konstitusi dari calon yang diusulkan Presiden, DPR, dan Mahkamah Agung tersebut.

i. DPR menetapkan APBN bersama Presiden dengan memperhatikan pertimbangan DPD.

j. DPR memberikan pertimbang an kepada Presiden untuk mengangkat duta, menerima penempatan duta negara lain, 
dan

memberikan

pertimbangan

dalam

pemberian amnesti dan

abolisi.

k. DPR memberikan persetujuan kepada Presiden untuk menyatakan perang, membuat perdamaian, dan perjanjian dengan negara lain.

1. Presiden membuat perjanjian internasional lainnya dengan persetujuan DPR.

3. Hubungan DPR dengan MA

Adapun pola hubungan antara lembaga negara DPR dan MA antara lain;

a. DPR bersama dengan bersama dengan MA dan Presiden mengajukan calon Hakim Konstitusi masing-masing 3 orang.

b. DPR dapat memberhentikan anggota MA di tengah jabatannya jika terbukti melanggar hukum dan asas kepatutan berdasarkan hukum yang berlaku.

c. MA memberikan pendapat hukum atas permintaan DPR mengenai suatu masalah yang dihadapi.
4. Hubungan DPR dengan BPK

Adapun pola hubungan antara lembaga Negara DPR dan BPK antara lain :

a. BPK menyerahkan hasil pemeriksaan keuangan negara kepada DPR, DPD, dan DPRD (sesuai dengan kewenangannya).

b. DPR membahas dan menindaklanjuti hasil pemeriksaan atas pertanggungjawaban keuangan negara yang disampaikan oleh Badan Pemeriksa Keuangan.

c. DPR memiliki kewenangan yang diantaranya menyangkut BPK yaitu dalam pemilihan, pengangkatan, dan pemberhentian anggota maupun pimpinan BPK merupakan atas kewenagan DPR. Oleh karena itu pencalonan anggota BPK haruslah datang dari DPR yang kemudian ditetapkan oleh Presiden.

5. Hubungan DPR dengan MK Hubungan antara lembaga negara DPR dan Mahkamah Konstitusi yaitu MK wajib memeriksa, mengadili, dan 
memberi putusan dengan seadiladilnya atas pendapat Dewan Perwakilan Rakyat mengenai dugaan pelanggaran

olehPresiden dan/ atau Wakil

Presiden menurut UUD NRI 1945 .

6. Hubungan DPD dengan Presiden

Hubungan antara lembaga Negara DPD dan Presiden yaitu DPD melakukan pengawasan atas pelaksanaan undang-undang oleh Presiden dalam hal ini pemerintah mengenai otonomi daerah, pembentukan, pemekaran, dan penggabungan daerah, hubungan pusat dan daerah, pengelolaan sumber daya alam, dan sumber daya ekonomi lainnya, pelaksanaan APBN, pajak, pendidikan, dan agama.

7. Hubungan DPD dengan MA

Hubungan antara lembaga negara DPD dan MA yaitu M A memberikan pendapat hukum atas permintaan DPD mengenai suatu masalah yang dihadapi.
8. Hubungan DPD dengan BPK

Hubungan antar lembaga negara DPD dan BPK yaitu :

a. DPD menerima hasil pemeriksaan keuangan negara dari BPK untuk dijadikan bahan membuat pertimbangan bagi DPR tentang RUU yang berkaitan dengan APBN.

b. BPK menyerahkan hasil pemeriksaan keuangan negara kepada DPR, DPD, dan DPRD (sesuai dengan kewenangannya) (Pasal 23E 2).

c. Dalam hal pemilihan anggota BPK, DPD memberikan pertimbangannya kepada DPR.

9. Hubungan DPD dengan MK Hubungan antara lembaga negara M K dan DPD yaitu MK menyelesaikan konflik atau sengketa karena adanya penyimpangan terhadap konstitusi yang dilakukan DPD, yang tidak dapat diselesaikan oleh peradilan umum.

10. Hubungan Presiden dengan MA 
Hubungan antara lembaga negara MA dan Presiden yaitu;

a. Dengan memperhatikan pertimbangan Mahkamah agung memberi grasi dan rehabilitasi.

b. Presiden bersama dengan bersama dengan $\mathrm{M} \mathrm{A}$ dan DPR mengajukan calon Hakim Konstitusi masingmasing 3 orang dan menetapkannya.

c. MA memberikan pendapat hukum atas permintaan Presiden mengenai suatu masalah yang dihadapi.

11. Hubungan Presiden dengan BPK

Hubungan antara lembaga negara Presiden dan BPK antar lain :

a. Presiden meresmikan anggota BPK.

b. BPK memeriksa penggunaan Anggaran Pengeluaran Belanja Negara yang berkaitan dengan keuangan negara dan kekayaan negara.

12. Hubungan Presiden dengan MK

Hubungan antar Lembaga Negara MK dan Presiden yaitu : a. MK menjaga pelaksanaan UUD oleh Presiden dalam hal ini pemerintah.

b. Presiden menetapkan Hakim Konstitusi yang dimiliki oleh MK.

13. Hubungan $\mathrm{M}$ A dengan BPK

Hubungan antara lembaga negara MA dam BPK yaitu MA memberikan pendapat hukum atas permintaan BPK mengenai suatu masalah yang dihadapi.

14. Hubungan MA dengan MK

Hubungan antara lembaga negara MA dan MK yaitu :

a. Mahkamah Agung bersama dengan Mahkamah Konstitusi melaksanakan kekuasaan kehakiman di Indonesia.

b. Mahkamah Agung mengadili suatu perkara pada tingkat kasasi, menguji peraturan perundang-undangan di bawah undang-undang terhadap undang-undang sedangkan Mahkamah

Konstitusi mengadili pada tingkat pertama dan terakhir yang putusannya bersifat final 
untuk menguji undang-undang terhadap undang-undang dasar.

c. MK memutus sengketa kewenangan lembaga negara yang kewenangannya diberikan oleh Undang-Undang Dasar.

15. Hubungan BPK dengan MK

Hubungan antara lembaga negara BPK dan MK, yaitu MK memutus sengketa kewenangan BPK yang kewenangannya diberikan oleh Undang-Undang Dasar.

\section{Kontroversi dalam Redistribusi dan Hubungan Kekuasaan Kekuasaan}

Konstitusi secara filosofi lahir untuk membentuk dan membatasi kekuasaan, sekaligus mengendalikan kekuasaan itu. Konstitusi yang kokoh (yang mampu menjamin demokrasi yang berkelanjutan) adalah konstitusi yang mengatur secara rinci batas-batas kewenangan dan kekuasaan lembagalembaga legislatif, eksekutif, dan yudikatif secara seimbang dan saling mengawasi (check and balance), sehingga tidak ada salah satu lembaga negara yang menjadi supreme, memberikan jaminan yang cukup luas bagi hak-hak warga negara dan hak asasi manusia.
Dengan demikian jelas bahwa kekuasaan antar lembaga negara itu tidak berdiri sendiri dan harus adanya keseimbangan yang diiringi dengan saling mengawasi (check and balance). Diskursus mengenai distribusi kekuasaan berdasarkan mekanisme check and balance selalu menjadi bahasan yang menarik, apalagi setelah UUD NRI 1945 telah berhasil diamandemen pada tahun 2002. Selama ini, dalam UUD NRI 1945 sebelum amandemen, masyarakat memandang kekuasaan Presiden terlalu besar (executive heavy), sedangkan lembaga negara lain kekuasaannya tidak seimbang dan tidak dapat saling mengawasi, bahkan terkesan sumir atau hanya sebatas pelengkap kenegaraan saja, sehingga dapat dikatakan bahwa UUD NRI 1945 sebelum diamandemen tidak memiliki mekanisme check and balance di dalamnya.

Setelah UUD NRI 1945 mengalami amandemen sebanyak empat kali, kekuasaan Presiden mengalami pengurangan yang cukup signifikan bahkan bisa dikatakan kekuasaan presiden seolah dikebiri akibat traumatik 32 tahun Republik Indonesia yang dikuasai oleh Presiden Soeharto. Pengurangan yang sangat signifikan itu sendiri justru terlalu 
timpang sehingga beralihlah

kekuasaan yang begitu besar di tangan

Presiden (executive heavy) pada UUD

NRI 1945 sebelum amandemen menjadi kekuasaan yang begitu besar di tangan lembaga Parlemen (legislative heavy) dalam UUD NRI 1945 hasil amandemen.

Salah satu kesepakatan dasar pada saat amandemen ialah mempertegas sistem pemerintahan presidensial, dan amandemen UUD NRI 1945 memiliki salah satu tujuan ialah menyempurnakan aturan dasar penyelenggaraan negara secara demokratis dan modern, antara lain melalui pembagian kekuasaan yang lebih tegas, sistem saling mengawasi dan mengimbangi (check and balance) yang lebih ketat dan transparan, dan pembentukan lembaga-lembaga negara yang baru untuk mengakomodasikan perkembangan kebutuhan bangsa dan tantangan zaman. $^{12}$ Pembahasan mengenai penerapan mekanisme check and balance dalam penulisan ini terbatas hanya pada kontroversi mekanisme check and balance dalam UUD NRI 1945 artinya kekuasaan lembaga negara yang di atur dalam UUD NRI

${ }^{12}$ Sekretariat Jendral MPR RI, Padauan Dalam Memasyarakat Undang-Undang Dasar Negara Republik Indonesia Tahun 1945, Sekretariat MPR RI, Jakarta, 2009, hlm.,8
1945 dan memiliki kontroversi saja yang akan di ulas sedangkan lembaga negara lain di luar UUD tidak dibahas.

Berikut akan dijabarkan kontroversi-kontroversi terkait redistribusi kekuasaan dalam tatanan kelembagaan Negara Indonesia berdasarkan UUD NRI 1945 hasil amandemen;

1. Terkait Kekuasaan Pembentuk Undang-Undang (Fungsi Legislasi)

Jimly Asshiddiqie dalam bukunya "Pengantar Ilmu Hukum Tata negara" menyatakan bahwa fungsi legislasi menyangkut empat bentuk kegiatan yakni; pertama, prakarsa pembuatan undangundang (legislative initiation); kedua, pembahasan rancangan undang-undang (law making process); ketiga, persetujuan atas pengesahan rancangan undangundang (law enactmen approval); dan keempat, pemberian persetujuan pengikatan atau ratifikasi atas perjanjian atau persetujuan international dan dokumen-dokumen hukum yang mengikat lainnya (binding decision making international law 
agreement and treaties or other

legal binding document). ${ }^{13}$

Permasalah utama dalam fungsi legislasi dalam UUD NRI 1945 ialah ikut sertanya Presiden dalam fungsi legislasi bahkan pengaruh dari keikutsertaan Presiden tersebut sangatlah kuat. Sebagaimana terdapat pada Pasal 5 ayat (1) yakni "Persiden berhak mengajukan RUU kepada DPR". Namun ketentuan mengenai legislasi tidak berhenti disana, ketentuan dalam Pasal lain yang berkenaan dengan pengaruh yang kuat terhadap RUU menjadi UU oleh Presiden terlihat dalam Pasal 20 ayat (2) "setiap RUU dibahas oleh DPR dan Presiden untuk mendapatkan persetujuan bersama" kemudian diikuti Pasal 20 ayat (3) "jika RUU tidak mendapat persetujuan bersama, RUU itu tidak dapat diajukan lagi dalam persidangan DPR masa itu". Memang pada dasarnya pengesahan RUU untuk menjadi UU ialah menjadi kewenangan Presiden namun pengesahan itu sendiri sesungguhnya tidak berimplikasi apapun yang mana apabila dalam 30 hari semenjak RUU tersebut

13 Jimly Asshiddiqie, Pengantar Ilmu Hukum Tata Negara, Rajawali Press, Jakarta, 2010, hlm 299 disetujui, $\quad$ Presiden tidak mengesahkannya menjadi UU maka RUU tersebut sah menjadi UU dan wajib diundangkan.

Dari ulasan di atas dapat kita lihat bahwa semula yang diimpikan mengenai keikutsertaan Presiden dalam fungsi legislasi adalah sebagai pelaksnaan mekanisme check and balance sesuai dengan prinsip separation of power yang di gunakan dalam sistem pemerintahan presidensial, namun seolah menjadi overlap dan Presiden sebagai pemegang kekuasaan eksekutif memiliki peranan yang kuat dalam kekuasaan legislative bahkan sama kuatnya. Jika diletakkan dalam system pemerintahan presidensial, keterlibatan Presiden dalam proses legislasi (pembentukan undangundang) yang begitu dalam dan jauh berpotensi menambah ketegangan hubungan antara eksekutif dan legislative. ${ }^{14}$

\section{Terkait Kekuasaan Yudikatif}

Kekuasaan yudikatif di negara Indonesia dipegang oleh 2 lembaga yakni Mahkamah Agung dan

14 Saldi Isra, Pergeseran Fungsi Legislatif Menguatnya Model Legislatif Parlementer Dalam Sistem Presidensial Indonesia, Rajawali Press, Jakarta, 2010, hlm 6 
Mahmakah Konstitusi. Dalam aspek ini permasalahan atau kontroversinya bukan pada mekanisme check and balance tetapi pada distribusi kekuasaan kehakiman antar kedua Mahkamah tersebut.

Seperti yang dijabarkan dalam UUD NRI 1945 Pasal 24A ayat (1) mengenai wewenang Mahkamah Agung yaitu mengadili pada tingkat kasasi, menguji peraturan perundang-undangan di bawah undang-undang terhadap undangundang, dan wewenang lain yang diberikan oleh undang-undang, sedangkan pada $24 \mathrm{C}$ ayat (1) mengenai wewenang Mahkamah Konstitusi ialah mengadili pada tingkat pertama dan terakhir yang putusannya final untuk menguji undang-undang terhadap UUD, memutus sengketa kewenangan antar lembaga negara yang kewenangannya diberikan oleh UUD, memutus pembubaran partai politik, dan memutus perselisihan tentang hasil pemilihan umum.

Idealnya, kekuasaan kehakiman yang berpuncak pada dua lembaga negara, yaitu MA dan MK, memilih wewenang secara tegas antara penangan atas konflik konvensional dan penangan atas konflik antar peraturan perundang-undangan. MA seharusnya terfokus untuk menangani peradilan konvensional (antar orang dan/ lembaga) sedangkan MK menangani peradilan berkenaan dengan konflik peraturan perundang-undangan. ${ }^{15}$

Namun berdasarkan ketentuan Pasal 24A ayat (1) dan 24C ayat (1), selain menangani peradilan konvensional, MA diberi juga wewenang menguji peraturan perundang-undangan di bawah UU terhadap peraturan perundangundangan yang lebih tinggi. Sedangkan MK, selain hanya menguji UU terhadap UUD, juga diberi kewenangan-kewenangan lain yang diluar konflik perundangundangan. Dengan pembahasan ini idealnya MK di beri kewenangan yang jelas yakni, kewenangan yang sepenuhnya untuk menguji peraturan perundang-undangan (judicial review) baik UU terhadap UUD maupun peraturan perundang-undangan di bawah UU terhadap peraturan perundangundangan di atasnya.

\footnotetext{
${ }^{15}$ Mahfud MD, Perdebatan Hukum Tata Negara Pasca Amandemen Konstitusi, Rajawali Press, Jakarta, 2010, hlm. 74.
} 
3. Bentuk dan Kewenangan Parlemen

Dalam kaitan dengan mekanisme check and balance diajukan pula gagasan perubahan terhadap sistem parlemen dari supremasi MPR yang terdiri dari tiga unsur (DPR, Utusan Daerah, dan Utusan Golongan) menjadi parlemen bikameral (dua kamar) yang terajut dalam hubungan check and balance dengan lembaga negara lainnya khususnya dengan lembaga eksekutif dan yudikatif. Gagasan ini menghendaki agar parlemen terdiri dari lembaga perwakilan politik yakni DPR dan lembaga perwakilan teritorial DPD. ${ }^{16}$

Semula gagasan ini memiliki cermin negara Amerika Serikat yang mana Parlemen (Kongres) di negara Amerika Serikat jelas menggunakan sistem bikameral yaitu dua kamar Kongres yakni House of Representative dan Senate. Di Amerika Serikat kedua kamar Kongres tersebut diletakkan dalam posisi yang seimbang dan saling mengawasi (check and balance). Namun berbeda dengan apa yang ada di UUD NRI 1945 hasil amandemen, yang mana ini

\footnotetext{
${ }^{16}$ Ibid., hlm. 68.
}

kemudian penulis angkat menjadi salah satu kontroversi distribusi kekuasaan pasca amandemen UUD NRI 1945.

Di mana MPR memang pada dasarnya tidak menjadi lembaga tertinggi negara lagi namun seolah seperti Kongres anggota MPR terdiri dari anggora DPR dan DPD (Pasal 2 ayat (1) UUD NRI 1945) seolah-olah menampung gagasan parlemen bikameral, namun dalam kenyataannya MPR tidak diberi fungsi legislasi, MPR bisa dikatakan lembaga negara yang mati suri dan hanya hidup atau memiliki tugas dan kewenangan yang jarang terjadi dalam konteks 5 tahunan masa bakti anggotanya. MPR memiliki kewenangan mengubah dan menetapkan UUD NRI 1945 (Pasal 3 ayat (1) UUD NRI 1945), bersidang sedikitnya satu kali dalam lima tahun di ibukota negara (Pasal 2 ayat (2) UUD NRI 1945), melantik Presiden dan Wakil Presiden (Pasal 3 ayat (2) UUD 1945), memberhentikan Presiden melalui mekanisme impeachment (Pasal 3 ayat (3) UUD 1945, memilih dua calon Wakil Presiden yang diajukan Presiden apabila terjadi kekosongan jabatan Wakil Presiden, dan yang 
terakhir memilih calon presiden dan calon wakil presiden yang diusulkan oleh partai politik atau gabungan partai politik peserta pemilu yang memiliki suara terbanyak pertama dan kedua pada pemilu presiden dan wakil presiden sebelumnya apabila Presiden dan Wakil Presiden mangkat atau diberhentikan (Pasal 8 ayat, (2), (3) UUD 1945).

Jika dilihat kewenangan MPR tersebut memang kewenangan yang kuat namun pada dasarnya kewenangan tersebut jarang terjadi adapun yang menjadi kewenangan atau tugas rutinya ialah bersidang sedikitnya sekali dalam lima tahun dan melantik Presiden dan Wakil Presiden, selebihnya bisa dikatakan jarang atau mungkin tidak terjadi dalam tempo waktu 5 tahun pengabdian anggotanya. Jika kembali kepada DPR, justru DPR memiliki peran yang kuat dan seolah menjadi satu-satunya cameral of parlemenfungsi legislasi contohnya, itu diberikan posisi yang kuat kepada DPR dan Presiden.

Dan untuk DPD fungsi legislasinya sangat terbatas dan hanya sampai pada proses pembahasan tidak pada proses penyetujuan dan pengesahan. Selain itu ada pula hak DPR yakni antara lain interpelasi, hak angket, dan hak menyatakan pendapat, dan hak anggota DPR untuk mengajukan usul RUU selain itu fungsi DPR yakni fungsi legislasi, fungsi anggaran, dan fungsi pengawasan yang mana mengakomodir DPR sebagai lemabaga yang heavy. Di dalam konstitusi hasil perubahan memang sama sekali tidak disebut istilah parlemen sehingga tidak mudah menjadikan DPR dan DPD sebagai kamar-kamar parlemen dua kamar.

4. Peran DPD yang Minim

Satu lagi yang menjadi kontroversi terkait redistribusi kekuasaan berdasarkan UUD NRI 1945 hasil amandemen yang masuk dalam peta penelitian ini, ialah peranan dan fungsi Dewan Perwakilan Rakyat (DPD) yang sangat minim. Meskipun kedudukannya merupakan salah satu lembaga negara yang sejajar dengan lembaga negara lain seperti Presiden, DPR, MPR, MK, MA, dan BPK, dan memiliki legitimasi kuat dari rakyat yang tercermin dalam pemilihan keanggotaanya yakni melalui pemilihan umum, 
ternyata DPD di dalam konstitusi ini hanya diberi fungsi yang sangat minim dan nyaris tak berarti jika dibandingkan dengan biaya politik dan proses perekrutannya yang sangat demokratis.

Bandingkan dengan lembaga perwakilan lain yakni DPR yang di dalam konstitusi diatur dalam tujuh pasal (Pasal 19, 20, 20A, 21, 22, 22A, 22B), sedangkan DPD hanya diatur dalam dua pasal $(22 \mathrm{C}$ dan 22D). dalam bidang legislasi misalnya DPD tidak dapat ikut menetapkan UU sebagaimana layaknya lembaga perwakilan rakyat, sebab dalam Pasal 20 ayat (1) UUD 1945 sudah mengunci bahwa yang memegang kekuasaan membentuk UU adalah DPR. Jika dilihat dalam ketentuan pasal 22C dan 22D maka kewenangan DPD itu hanya;

1. Mengajukan RUU dalam bidang otonomi daerah, hubungan pusat dan daerah, pembentukan dan pemekaran serta penggabungan daerah, penggabungan sumber daya alam dan sumber daya ekonomi lainnya, perimbangan keuangan pusat dan daerah;

2. Ikut membahas RUU dalam bidang otonomi daerah, hubungan pusat dan daerah, pembentukan dan pemekaran serta penggabungan daerah, penggabungan sumber daya alam dan sumber daya ekonomi lainnya, perimbangan keuangan pusat dan daerah;

3. Memberi pertimbangan terkait RAPBN, pajak, pendidikan, dan agama serta memberikan pertimbangan terkait pemilihan anggota Badan Pemeriksa Keuangan (BPK);

4. Melakukan pengawasan di bidang otonomi daerah, hubungan pusat dan daerah, pembentukan dan pemekaran serta penggabungan daerah, penggabungan sumber daya alam dan sumber daya ekonomi lainnya, perimbangan keuangan pusat dan daerah, APBN, pajak, pendidikan, dan agama.

Dengan kewenangan yang sangat terbatas ini dapat disimpulkan bahwa DPD hanya sebagai formalitas konstitusional belaka dikatakan oleh Mahfud MD dalam bukunya Perdebatan Hukum Tata Negara Pasca Amandemen Konstitusi, DPD tidak mempunya fungsi ketatanegaraan yang berarti. Peran-perannya yang sering dilakukan untuk menyampaikan aspirasi rakyat daerah terhadap 
pusat sebenarnya dapat dilakukan oleh Ormas, LSM atau media massa. DPD hanya menjadi penting kalau terjadi sesuatu yang akan jarang terjadi yang sifatnya insidental berdasarkan UUD NRI 1945, yakni terjadinya perubahan atas UUD NRI 1945 dan terjadinya impeachment terhadap Presiden dan/atau Wakil Presiden yang prosesnya sampai ke MPR. ${ }^{17}$

\section{KESIMPULAN}

Redistribusi kekuasaan lembaga negara sebelum amandemen UUD NRI 1945;

1. Adanya lembaga tertinggi negara.

2. Adanya executive heavy karena kekuasaan membentuk UU ada di tangan presiden sekaligus presiden memegang kekuasaan pemerintahan dan presiden dapat ikut campur dalam pengadilan.

Sesudah amandemen UUD 1945:

1. Tidak ada lembaga tertinggi negara dan kedaulatan berada di tangan rakyat.

2. Adanya pergeseran kewenangan kekuasaan legislatif yang dialihkan dari kekuasaan presiden kepada DPR Yang

\footnotetext{
${ }^{17}$ Ibid., hlm. 72.
}

kemudian lebih berkesan pada legislative heavy.

3. Adanya sistem pengawasan dalam kekuasaan kehakiman.

Hubungan antara lembaga negara (checks and balance) tidak terlepas dari kisah klasik sistem ketatanegaraan Indonesia, di mana adanya domain eksekutif yang berlebih yang kemudian memunculkan sistem pemerintahan yang condong pada tirani dan otoriter, yang kemudian Indonesia bisa dikatakan mengadopsi konsep check and balances dengan menerapkan adanya fungsi pengawasan dari tiap-tiap lembaga negara misalnya, dalam hal legislasi pada era reformasi ini dilakukan bersama-sama Presiden dengan DPR, lalu adanya sistem judicial review yang dilakukan oleh MK, Komisi Yudisial sebagai lembaga yang mengawasi hakim dalam sistem peradilan.

Kontroversi dalam redistribusi kekuasaan di negara Indonesia berdasarkan UUD NRI 1945 dapat dilihat dari berbagai persoalan yang kemudian timbul dari apa yang diamanatkan UUD NRI 1945. Kontroversi tersebut terkait adanya ketidaksinambungan dalam pendistribusian lembaga negara 
mulai dari adanya overlap kekuasaan presiden dalam ikut serta membahas UU bersama DPR, adanya kebingungan terkait pembagian antara wewenang MA dan MK dalam perspektif ketatanegaraan, tidak konsistennya sistem parlemen yang ingin diberlakukan serta minimnya kewenangan DPD dalam parlemen.

Kiranya perlu dilakukan pembenahan ulang serta pembahasan yang lebih mendalam tentang konsep apa yang kemudian pas dalam sistem ketatanegaraan Indonesia, khususnya menyangkut pendistribusian kekuasaan atau mungkin separation of powe ryang kemudian dapat berdampak pada optimalisasi kinerja tiap-tiap lembaga negara demi mencapai cita-cita negara yang tertuang dalam Preambule UUD NRI 1945 alinea ke-4.

\section{DAFTAR PUSTAKA}

Asshiddiqie, Jimly, 2006, Pengantar Hukum Tata Negara Jilid II, Sekretariat jendral dan Kepaniteraan Mahkamah Konstitusi, Jakarta. , 2009, "Menuju Negara Hukum yang Demokratis" PT Buana Ilmu Populer, Jakarta.
, 2010, Pengantar Ilmu Hukum Tata Negara, Rajawali Press, Jakarta.

Isra, Saldi, Pergeseran Fungsi Legislatif Menguatnya Model Legislatif Parlementer Dalam Sistem Presidensial Indonesia, Rajawali Press, Jakarta.

Mahfud MD, Moh, 2010, Perdebatan Hukum Tata Negara Pasca Amandemen Konstitusi, Rajawali Press, Jakarta.

Mahfud MD, Moh, 2013 , Perdebatan Hukum Tata Negara Pascaamandemen Konstitusi, Raja Grafindo Persada : Jakarta.

Sekretariat Jendral MPR RI, 2009, Padauan Dalam Memasyarakat Undang-Undang Dasar Negara Republik Indonesia Tahun 1945, Sekretariat MPR RI, Jakarta.

Soemantri, Sri, 2008, "lembaga Negara dan State Auxiliary Bodies dalam Sistem Ketatanegaraan Menurut UUD 1945", dalam Departemen Hukum Fakultas Hukum Unair.

C.F. Strong, "Modern Political Constitusional", terjemahan cetakan ke-10, Nusa Media, Bandung.

Suny, Ismail, 1986, Pergeseran Kekuasaan Eksekutif, cetakan ke-5, Aksara Baru, Jakarta. 